\title{
Vztah jedinců staršího věku k pohybové aktivitě
}

\section{Relationship of physical activity for elderly people}

\author{
Gabriela Stará, Jitka Kopřivová
}

Fakulta sportovních studií Masarykovy univerzity, Brno

\begin{abstract}
Abstrakt:
Článek shrnuje názory účastníku intervenčního pohybového programu pro seniory na jejich vztah $k$ pohybové aktivitě a sportu. Jsou zde rozebírány otázky vykonávané pohybové aktivity v průběhu života, motivace $k$ účasti na intervenčním programu, pocity spojované se cvičenim, vztahy ve skupině a aktivity seniorů mimo intervenční program.
\end{abstract}

\begin{abstract}
:
This article aims to sum up a responses by volunteers of the intervention mobility program for elder$l y$ population and their views on their own relationship with physical exercise and a sport. It explores the questions about their own physical activity throughout their life and their motivation for joining this program. Also it describes their feelings about the excise, a relations with other clients of this program and their other activities apart from this program.
\end{abstract}

Klícová slova: $\quad$ senioři, pohybové aktivity, intervenční pohybový program

Key words: $\quad$ elderly people, motor activities, interventional motor program

\section{ÚVOD}

Cílem tohoto článku je analýza získaných výsledků části ankety, která byla uskutečněna v rámci intervenčního pohybového programu pro seniory realizovaného pod záštitou Fakulty sportovních studií Masarykovy univerzity. Tento projekt probíhá od r. 2003 a je koncipován především pro udržení a zlepšení kvality života zúčastněných seniorů. Prezentovaná anketa je jednou metod získávání dat v širším výzkumném šetření a doplňuje komplexní empirický výzkum týkající se analýzy vztahu životní spokojenosti a pohybové aktivity u skupiny seniorů, u kterých je pohybová aktivita pravidelně stimulována. Další data pro celý výzkum byla získána pomocí Dotazníku životní spokojenosti (Fahrenberg et al., 2001) a pomocí pozorování.

Období stárnutí a stáří je spojeno s osobami seniorského věku. V tomto kontextu se můžeme setkat s různými pojmy: geront, senescent, důchodce nebo starý. V současné době se ustálil termín senior, který je považován za významově neutrální a nahrazuje specifické označení starého člověka z pohledu různých vědeckých disciplín. Stárnutí a stáří souvisí s klasifikací dle věku (Kozáková et al., 2006). K pojmu stáří logicky přiřazujeme období na sklonku života. Stáŕí lze vymezit z pohledu kalendářního (chronologického, matričního), biologického (funkčního věku), sociálního (sociálněhistorický věk) a psychického věku.

Pohybovým programem jsme se snažili působit proti neustálému růstu tzv. somatomentální disharmonie (Kavalíř 2007), který je spojován se sedavým způsobem života doprovázeným nevhodnou životosprávou, a působit tak na zkvalitnění života probandů. Pohyb má v tomto smyslu neopomenutelnou úlohu. At pohyb tělesný nebo myšlenkový je spojnicí, která nás propojuje se světem. Pokud myslíme a pohybujeme se, potud žijeme a jsme svobodnými účastníky dění kolem nás (Kubíčková 1996).

Pohyb je velmi důležitým indikátorem kvality života. Kvalita života je vymezována jako udržení si samostatnosti a relativní bohatosti života korunované jistou mírou životní spokojenosti. Pohybová aktivita je zde na jedné straně předpokladem, ale na straně druhé i symptomem kvality života lidí (Hošek 2007).

V práci je dále zkoumán faktor motivace. Pojem motivace vysvětluje Blahutková $(2005$, s. 35) jako obecné označení všech podmínek, které determinují lidskou aktivitu. Jde o proces usměrňování, udržo- 
vání a energetizace chování. Za každým lidským činem hledáme příčinu, důvod, který způsobil takovou reakci. V zaměření motivace se uplatňuje osobnost jedince, jeho hierarchie hodnot i dosavadní zkušenosti, schopnosti a dovednosti.

\section{Metodika}

Zmíněný intervenční program probíhá osmým rokem. Jedná se o komplexní program, jehož cílem je rozvoj jak motorických schopností, tak psychické a sociální stránky osobnosti zúčastněných seniorů. V oblasti motorických schopností jsme používali cvičení ve formě aerobního zatížení působící na rozvoj síly a vytrvalosti. V oblasti psychické jsme působili především na kognitivní funkce (zejména pamět'), v sociální oblasti se jednalo o cvičení zaměřená na spolupráci a komunikaci v rámci kolektivu. K dosažení stanovených cílů jsme používali zejména následující prostředky: cvičení zdravotní tělesné výchovy (bez náčiní i s pomůckami), cvičení a hry z oblasti psychomotoriky, pamětové hry a relaxační cvičení. Intervenční program byl uskutečňován v Domově pro seniory na Vychodilově ulici v Brně. Cvičební lekce v délce 60 minut probíhaly pravidelně dvakrát týdně.

\subsection{Výzkumná metoda}

Předkládaná anketa byla jednou $\mathrm{z}$ metod použitých $\mathrm{k}$ získávání dat $\mathrm{v}$ rámci širšího výzkumu. Cílem převážně kvalitativního zkoumání bylo odpovědět na otázky, které souvisejí s pohybovou aktivitou a jejím působením na determinanty psychosociálního stavu u aktivně zapojených seniorů. Pro řešení zkoumaného problému byl využíán design mnohonásobné případové studie. Při výběru přístupu ke zkoumanému problému jsme se ř́́dili definicí Hendla (2005).

Pro celý výzkum byly stanoveny následující výzkumné otázky:

1. VO 1: Jaký je individuální obraz životní spokojenosti seniorů navštěvujících intervenční cvičební program?

2. VO 2: Jakým způsobem ovlivňuje pohybová aktivita a sport životní spokojenost těchto seniorů?

Pomocí dat získaných z prezentované ankety jsme se snažili částečně odpovědět na druhou výzkumnou otázku tohoto výzkumu.

\subsection{Metodika sběru dat}

Data pro hodnocení byla získána z empirického šetření, které jsme provedli v červnu roku 2010 během cvičebních lekcí intervenčního pohybového programu v Domově pro seniory na Vychodilově ulici v Brně.

V rámci ankety jsme načerpali data pro provázání všech dosavadních získaných dílčích výsledků našeho výzkumu. Anketa, která obsahovala 91 otázek, se týkala následujících oblastí: sociologických dat účastníků, vztahu seniorů ke sportu a k pohybovým aktivitám, hodnocení intervenčního programu, motivace k účasti na cvičení, pocitů spojených se cvičením, změnami spojenými s návštěvou cvičení, vztahů ve skupině a dalších aktivit probandů mimo intervenční program.

Abychom získali co nejvíce informací kvalitativními metodami, byl při předložení této ankety s převahou otevřených otázek respondentům k dispozici výzkumník a dvě další poučené osoby. Jednalo se o kolegy, kteří se také podílejí na vedení intervenčního cvičebního programu. Snažili se zodpovědět veškeré př́padné dotazy seniorů, abychom získali data co nejvíce podobná polořízenému rozhovoru. Zvolené otázky doplňují dříve získané informace z Dotazníku životní spokojenosti (Fahrenberg et al., 2001).

\subsection{Výběr př́ípadu}

Šetření se zúčastnilo 24 probandů, z čehož bylo 22 žen a 2 muži. Jednalo se o záměrný výběr. Př́ípadem $\mathrm{v}$ tomto šetření rozumíme muže a ženy v seniorském věku, kteří se aktivně a pravidelně zúčastňují prezentovaného intervenčního programu. Průměrný věk žen činil 74 let, mužů 86 let.

$\mathrm{Z}$ uvedených údajů je zřejmé, že se jedná o velkou převahu žen nad mužskou složkou. Snažili jsme se přinést odpověd', proč se programu účastní v převážné většině ženy, ale nenalezli jsme žádný prokazatelný důvod. Můžeme na tomto místě pouze konstatovat, že dámy v seniorském věku vyhledávají růz- 
né skupinové aktivity, a naopak muži tolik družní nejsou. K tomuto problému se vyjadřují i další autoři (např̀. Kalvach et al., 2004) kteří uvádějí, že i mnohá zahraniční literatura konstatuje stejný problém, tedy nízké procento mužů účastnících se obdobných výzkumů. Také Štilec, Bunc (2007, s. 234) uvádějí ve svém pohybovém programu pro seniory $90 \%$ účast ženské složky.

Z 22 účastnic intervenčního programu dosáhly 2 seniorky (8\%) vysokoškolského vzdělání, 16 účastnic (76\%) středoškolského vzdělání. Pouze 3 účastnice (12\%) se vyučily (SŠ vzdělání bez maturity) a 1 účastnice (4\%) měla základní vzdělání. Ženy získaly své vzdělání nejčastěji na obchodní akademii, tuto školu úspěšně absolvovalo $68 \%$ účastnic našeho intervenčního programu. Oba muži mají úplné středoškolské vzdělání s maturitou dosažené v technických oborech. Podobné výsledky publikovali i Štilec, Bunc (2007, s. 234), kteř́ zmiňují, že v jejich intervenčním programu se jednalo převážně o stř̌edoškolsky a vysokoškolsky vzdělané zájemce.

Podle ČSÚ ve skupině 60 a více let byl podíl středoškolsky vzdělaných lidí s maturitou u obou pohlaví o něco vyšší než čtvrtinovýi. U žen ve skupině 60 a více let dosáhlo $35 \%$ pouze základního vzdělání, případně zůstalo bez vzdělání, $35 \%$ žen se vyučilo, $5 \%$ dosáhlo vysokoškolského vzdělání. Data jsou průměry za rok 2008 (http://www.czso.cz). Z těchto dat je patrné, že jsme oproti průměru ČR pracovali s velice vzdělanou skupinou obyvatel daného věku.

Získanému vzdělání odpovídalo také pracovní uplatnění probandů. $\mathrm{V}$ aktivním věku ženy nejčastěji pracovaly jako účetní, mzdové účetní, administrativní pracovnice, vedoucí pracovnice jednotlivých firemních úseků. Jejich zaměstnání bylo většinou sedavého charakteru, takto odpovědělo téměř $80 \%$ dotázaných žen. Práce mužů také odpovídala jejich dosaženému vzdělání, oba pracovali jako vedoucí pracovníci v technických oborech, i jejich zaměstnání bylo sedavého charakteru.

Dle vyhodnocených dat můžeme konstatovat, že intervenční program navštěvuje skupina seniorů $s$ převážně středoškolským a vysokoškolským vzděláním. Tito probandi mají zájem o setkání s podobně orientovanými vrstevníky, jako jsou sami, a o navazování nových sociálních vazeb. Vyšší vzdělání s sebou přináší snahu o udržování přehledu. Díky pravidelnému získávání informací jsou si všichni účastníci programu vědomi pozitivního vlivu cvičení na svůj zdravotní stav.

\section{Výsledky a diskuse}

\subsection{Vztah účastníků ke sportu}

V naší práci se zabýváme otázkou vztahu účastníků intervenčního programu ke sportu a pohybové aktivitě jak v současnosti, tak v průběhu celého života. Zajímalo nás, zda můžeme usuzovat na vazbu celoživotního provádění výkonnostního sportu nebo pohybové aktivity a současnou aktivní účast na intervenčním programu, tedy zda může být důvodem $\mathrm{k}$ pravidelné návštěvě cvičebních lekcí ve vyšším věku zvyk z mládí pravidelně vykonávat pohybové aktivity nebo sport. Tato vazba se nám však u žen nepotvrdila. Pouze 2 dámy (tj. $9 \%$ účastnic) z 22 provozovaly výkonnostní sport. Na rozdíl od žen oba muži uvedli, že se v mládí výkonnostnímu sportu věnovali (fotbal, házená). U pánů tedy tuto souvislost nacházíme. Celkově ale v mládí a ve středním věku sportovalo pouze $17 \%$ účastníků intervenčního programu. Předpokládali jsme, že důvod návštěvy intervenčního programu mohl také pramenit $\mathrm{z}$ dřívější aktivní účasti na vrcholovém sportu, tento důvod se nám však naprosto nepotvrdil. Nikdo z účastníků nevykonával v dřívějších letech vrcholový sport. Štilec, Bunc (2007, s. 234) ze svého výzkumu uvádějí následující data: $37 \%$ účastníků nikdy pravidelně nesportovalo. Sport převážně rekreační provozovalo pouze $27 \%$ seniorů.

Dále jsme se dotazovali na druhy vykonávaných sportů a pohybových aktivit v různých obdobích života (dětství, stř̌ední věk, stáŕí). Z vykonávaných sportů a pohybových aktivit v dětství u seniorek nejvíce převládá cvičení v Sokole, dále přirozené dětské pohybové aktivity, turistika, plavání, rytmika, jízda na kole, bruslení, atletika, gymnastika, lyžování, balet, házená, volejbal. Ve středním věku zastoupení pohybové aktivity v životě žen slábne. Šest žen žádnou pravidelnou pohybovou aktivitu nevykonávalo. Pokud dámy ve stř̌edním věku sportovaly, uváděly turistiku a vycházky, cvičení, plavání, jógu, objevují

1 Do skupiny úplné stř̌edoškolské vzdělání řadí ČSÚ všechny typy studia s maturitou a nástavbové studium. 
se nácviky na spartakiádu, volejbal, bruslení, společenský tanec, jízda na kole. V seniorském věku bývají zmiňovány pouze vycházky, případně jízda na kole, plavání. Alternativou pak většinou bývá práce na zahrádce, případně další pohybové aktivity mimo náš intervenční program. 15 probandek $(68 \%)$ odpovědělo, že intervenční program je v současnosti jejich jedinou pohybovou aktivitou. 5 žen (23\%) uvedlo, že se nyní věnují i dalším aktivitám. Nejčastěji byly uváděny dlouhé procházky, jízda na kole, plavání, fyzická práce, jízda na koloběžce jako doprovod vnuka, běh na lyžích. Musíme podotknout, že se jedná především o mladší účastnice intervenčního programu. Sedm starších účastnic uvádí jako jedinou pohybovou aktivitu tento intervenční program.

V návštěvě intervenčního programu $75 \%$ žen podporuje rodina. Negativně se vyjádřilo $25 \%$. V těchto př́ípadech žijí většinou dámy ve vlastních domácnostech a o svých aktivitách si rozhodují sami. 6 žen na tuto otázku neodpovědělo, většina $\mathrm{z}$ nich nemá vlastní děti, proto neodpovídaly.

Na rozdíl od žen muži uvádí široké spektrum aktivně vykonávaných sportů. V dětství lyžování, plavání, házená, atletika, volejbal, bruslení. Ve středním věku pokračuje lyžování, volejbal, fotbal, plavání, bruslení. Oproti ženám v seniorském věku muži žádnou další pohybovou aktivitu mimo intervenční program neuvádí. U obou mužů rodina cvičení podporuje.

$Z$ výše uvedeného je patrné, že ženy jsou ve starším věku výrazně aktivnější v oblasti pohybových aktivit než muži. Většina žen vyhledává i další aktivity např. procházky, ale stále vykonává i fyzickou práci, úklid domácnosti, zajištuje všechny potřebné domácí práce, hlídá vnuky, což u mužů absentuje.

\subsection{Motivace $\mathrm{k}$ účasti $\mathrm{v}$ intervenčním pohybovém programu}

Jeden ze zásadních bodů našeho výzkumu vidíme v motivačním faktoru k účasti seniorů na intervenčním programu. Domnívali jsme se, že senioři budou od pravidelné pohybové aktivity očekávat pozitivní vliv na své zdraví. Položili jsme tedy otázku, jakou změnu od cvičení očekávali, než začali navštěvovat intervenční program, a zda se tato změna naplnila. Dámy uváděly následující odpovědi: „Zlepšení fyzického stavu.“ „Malou fyzickou zátěž prospěšnou zdraví.“ „Budu pohyblivější, chtěla jsem zhubnout.“ „Vypadat lépe a radostně.“ „Udržet se alespoň ve stejné kondici.“ „Zlepšit držení těla." Dủležitým poznatkem je, že všechny ženy odpověděly kladně ohledně změny. Pokud tedy začínaly cvičit s určitým předpokladem ke zlepšení, všem se naplnil. 76 \% žen odpovědělo na otázku „Naplnila se tato změna? Ano, zcela“, 24 \% žen „Ano, částečně.“ Další reakce byly: „Lepší pohyblivost a něco již tak nebolí“, „Klouby bolí méně“, „Zhubla jsem nějaké kilo.“ Negativními reakcemi byl u dvou dam nedosažený váhový úbytek. Naším cílem však nebylo sestavovat intervenční program pro redukci hmotnosti. Fyzická zátěž by musela být výrazně vyšší, což vzhledem k zdravotnímu stavu některých účastníků nebylo možné. Muži odpovídali: „Očekával jsem zlepšení zdravotního stavu, změna se částečně naplnila.“ a „Očekával jsem fyzickou aktivitu a dobrý duševní pocit a změna se zcela naplnila.“

Dủležitým momentem při vykonávání pohybové aktivity je její pravidelnost. Proto jsme se dotazovali, jak často senioři cvičí a zda cvičí i sami doma. Z 22 dam intervenční program dvakrát týdně navštěvuje 20 (91\%). 2 dámy (9\%) se účastní pouze 1 x týdně, jedné nevyhovuje současný dopolední čas jedné z lekcí, druhá nemá vztah $\mathrm{k}$ tanci (náplň jedné z lekcí). Oba muži navštěvují intervenční program dvakrát týdně. Dále z ankety vyplynulo, že 21 probandek (95\%) vykonává pohybovou aktivitu také doma, oba muži též pravidelně doma cvičí. Každý den cvičí 16 seniorek (73\%). Ostatní dámy cvičí nepravidelně. Pouze 1 seniorka doma necvičí, nebot další pohybovou aktivitu kompenzuje fyzickou prací v rámci výdělečné činnosti. Jeden z pánů cvičí doma pravidelně denně, druhý pouze jedenkrát týdně. I zde můžeme spatřovat mírně aktivnější prrístup žen.

Další zkoumanou oblastí byly důvody neúčasti na intervenčním programu. 18 žen za hlavní důvod neúčasti na cvičební lekci považuje nemoc. Mezi další možné důvody patří především hlídaní vnoučat, nepřizeň počasí (sníh, led), návštěvy lékaře, nečekané návštěvy a jiné neodkladné povinnosti. Muži uvedli zdravotní potíže, osobní indispozice, návštěvu lékaře a někdy i počasí. Z odpovědí je zřejmé, že probandi berou účast na intervenčním programu zcela vážně a svědomitě a mimo jmenované příčiny se vždy cvičebních lekcí účastní. 
Součástí ankety byla otázka „Jaká je vaše motivace jít na cvičení?“ Odpovědi jsme se snažili rozdělit do tř́i oblastí:

1. kladné působení na fyzický stav (tělesná stránka);

2. zlepšení psychosociálního stavu (pocity, komunikace);

3. př́nos pro zdraví (pokud nebylo specifikováno blíže).

Předpokládali jsme, že senioři uvedou ve většině př́ípadů odpověd’ typu „Zlepšení pohyblivosti“ nebo „Zlepšení fyzického stavu“. U mužů jsme získali odpovědi „Je mi v našem kolektivu dobře“ a „Udělat něco pro zdraví, což náš předpoklad nepotvrdilo. První odpověd’ náleží do skupiny zlepšení psychosociálního stavu, druhou odpověd řadíme do 3. skupiny - přínos pro zdraví.

U žen jsme vyhodnotili 16 podnětů pro kladné působení na fyzický stav („Pohyb“, „Abych si udržela tělo v chodu“, „Rozhýbat se“, „Zlepšení pohyblivosti“, „Udržet si dobrou kondici“ atp.) a 17 podmětů pro zlepšení psychosociálního stavu („Dobrý kolektiv“, „Setkání se známými, přáteli, kamarádkami“, „Pobavit se“, „)ít z domu ven“, atp.). Obecně př́nos pro zdraví byl u žen uveden čtyřikrát („Udělat něco pro zdraví“). Překvapilo nás, jak velkým podílem byla zastoupena motivace v oblasti zlepšení psychosociálního stavu, aniž by ji ženy jakkoliv spojovaly se zlepšeným fyzickým výkonem a zdravotním stavem. Často se také vyskytovaly kombinace kladného působení na tělesnou stránku a současně kladné působení na psychosociální stav. S podobnými závěry přichází i Hošek (2007, s. 8), který uvádí, že pohybová aktivita může výrazně přispět ke kvalitě života u seniorů, kde kupodivu sociální užitek převažuje nad biologickými benefity pohybových aktivit.

K hlavním motivačním faktorům účasti v intervenčním programu tedy patří zvýšení kvality života ve stáří díky kladnému působení na zdraví, zachování si co nejdelší vlastní soběstačnosti, udržování práátelských vazeb v kolektivu vrstevníků, a pozitivně tak působit na svou psychiku.

Pro vlastní zpětnou vazbu jsme také položili otázku týkající se skladby cvičebních lekcí. Zajímalo nás, co seniorům vyhovuje, jakou náplň hodin preferují. Na tuto otázku probandi odpovídali volně, proto odpovědi pouze shrneme do skupin a okomentujeme. Někteří uvedli i více druhů cvičení, jiní naopak napsali pouze „Skladba hodin mi vyhovuje.“ nebo „Cvičení všeho druhu mi vyhovuje“. Jednalo se vždy o kombinaci cvičení zdravotní tělesné výchovy bez pomůcek s nějakým zpestřením, např. s cvičením s pomůckami, s tancem apod. Ženy uváděly: cvičení zdravotní tělesné výchovy bez pomůcek, tanec, cvičení všeho druhu, cvičení s pomůckami, relaxační cvičení, hry (v praxi jsou zařazovány psychomotorické hry), jógová cvičení, pamětové hry. Pánové odpověděli každý jinak, první nepreferoval žádnou určitou skladbu hodiny, vyhovuje mu jakýkoliv druh cvičení, druhý muž uvedl cvičení s pomůckami. Odpovědi jsou seřazeny dle četnosti.

\subsection{Pocity spojené se cvičením}

$\mathrm{Na}$ tomto místě se pokusíme popsat pocity cvičenců spojené s vykonáváním pohybové aktivity a citovat některé odpovědi na otázku „Co vám cvičení přináší?“ Převažovaly odpovědi typu: „Uvolnění, dobrou náladu, rozhýbání celého těla“, „Pospolitost, radost ze cvičení“, „Radost ze setkání se cvičenci“, „Radost ze života“. Pokud senioři uvedli více odpovědí, brali jsme v úvahu všechny. Z odpovědí je jasné, že můžeme mluvit o pozitivním pocitovém hodnocení všemi dotázanými. Můžeme říci, že senioři mají s vykonáváním pohybové aktivity spojeny pozitivní emoce. Toto pozitivní hodnocení dokládá i fakt, že jen velmi malé procento účastníků přestalo intervenční program navštěvovat. Pokud k tomu došlo, jednalo se především o starší účastníky programu (nad 80 let, většinou ze zdravotních důvodů), nebo naopak okamžitě po pár lekcích ukončily účast v programu 2 dámy, které byly mladšího věku a ještě vyhledávaly fyzicky náročnější typ cvičení. Pozitivní hodnocení může souviset i s tím, že je seniorům zdůrazňováno, že mají vždy cvičit jen ty cviky, které na ně dobře působí, a vynechávat cviky náročné a bolestivé, a také vždy přihlédnout ke svému aktuálnímu zdravotnímu stavu. Cvičební program je tak koncipován zejména $\mathrm{z}$ důvodů objektivních zdravotních rizik, která se často u seniorů objevují.

Anketa obsahovala také konkrétní otázku, zda senioři cvičí všechny cviky, nebo některé vynechávají. 15 seniorek odpovědělo, že během jednotlivých lekcí cvičí všechny cviky, snaží se žádný nevynechat. V sedmi př́ípadech uvedly ženy, že některé cviky vynechávají. Cviky neprovádějí, pokud jsou nad jejich 
síly, pokud nestačí s dechem nebo by jim mohly zvýšit krevní tlak, např. mírné předklony. Cviky, při kterých je bolí kolena, ramena (bolest kloubů) atp. Muži na rozdíl od žen odpovídali striktně, že žádné cviky při cvičení nevynechávají. $Z$ toho usuzujeme, že ženy podstatně lépe vnímají své tělo a dokážou reagovat na navozenou situaci, lépe se sebehodnotí, dokážou korigovat vykonávanou tělesnou zátěž, a proto by na ně mohlo cvičení působit po psychické stránce lépe. Toto tvrzení dokresluje názor Fialové (2007, s. 21), že míra sebepoznání, sebehodnocení i sebekontroly, zprostředkovaně pak celková životní spokojenost, mají význam pro kvalitu života.

Dotazovali jsme se také na pocity spojované se cvičením, a to formou otázek: „Jak se cítíte před cvičením?" „Jak se cítíte během cvičení?" „Jak se cítíte po cvičení?" Všechny získané reakce byly pozitivní. 41 \% žen odpovědělo „Na cvičení se těším“, některé dodaly, „těším se na kolektiv“. $23 \%$ žen napsalo „Mám dobré pocity“, $9 \%$ žen „Chci udělat něco pro své zdraví, $9 \%$ „Jsem trochu bolestivá, přijde uvolnění“. Shodně vždy 4,5\% žen uvedlo „Mám radost“, „Mám výborné pocity“, „Abych nezmeškala“, „Někdy se mi nechce“. Pokud se jim nechce, např. pro špatné počasí, tento pocit překonají, a po cvičení je kompenzován lepší náladou. Při cvičení se ženy cítí příjemně. Žádná z dotázaných neodpověděla, že se po cvičení cítí hůře. Některé jsou po cvičení trochu unaveny, ale psychicky dojde při cvičení a po cvičení k uvolnění těla a jsou navozeny dobré pocity. Pro př́klad uvádíme některé odpovědi: „Před cvičením mám dobré pocity, že se rozcvičím“, „Před cvičením se cítím hůř, ale lepší se mi nálada“, „Při cvičení jsem uvolněná, po cvičení trochu unavená“, „Po cvičení je mi dobře na těle i na duši“, „Po cvičení je mi lépe“, „Před cvičením se cítím dobře, chodím do cvičení ráda. Někdy se mi nechce, občas jsem líná, ale přemohu to a jdu. Během cvičením se cítím výborně, i kolektiv na mě dobře působí. Po cvičení jsem trochu unavená, ale zdravě, a zlepší se mi psychika“, „Před cvičením se někdy cítím bolavě, př̀i cvičení se uvolním, po cvičení je mi př́iemně“.

Muži odpovídali obdobně jako ženy, jeden uvedl „Mám dobré pocity před cvičením“, „Během cvičení se cítím dobře, mám rád aktivitu“, „Po cvičení jsem unaven, ale je mi dobře“. Druhý „Na cvičení se těším“, „Během cvičení se cítím dobře, po cvičení také“. Můžeme říci, že jsme pomocí své ankety dospěli k obdobným výsledkům jako Štilec, který použil pro své zpracování Škálu nálad a pocitů (Hátlová 1997 in Štilec 2001).

Další část dotazů směřovala k vlivu cvičení na fyzickou sebejistotu, cítí-li se senioři fyzicky lépe od té doby, co chodí na cvičení. A také na oblast psychiky, zda má pro seniory cvičení pozitivní vliv na jejich psychosociální stav, a pro kterou z oblastí má cvičení větši přínos. Na otázku „Cítíte se fyzicky lépe od té doby, co chodíte na cvičení?“, odpovědělo 18 probandek kladně, v dalších případech byly vždy po jedné uvedeny tyto odpovědi: „Cítím se dobře vždy“, „Jsem štastná, že se necítím hůřr“, „Cítím se stejně“, „Ne, měla jsem dost pohybu i dříve“. Nikdo neuvedl, že se cítí hůr.r.

$\mathrm{Na}$ otázku „Má cvičení pozitivní vliv na vaši psychiku?“, odpověděli oba muži kladně, také ženy odpovídaly pozitivně, 20 respondentek uvedlo „ano“, 2 odpověděly „asi ano“. Opět se nevyskytla žádná negativní odpověd. Poslední otázkou položenou této skupině bylo srovnání přínosu cvičení pro fyzický stav a psychosociální stav. Muži odpovídali rozdílně, první uvedl, že cvičení má stejný vliv jak na fyzický stav, tak na stav psychosociální. Druhý respondent uvedl, že cvičení má větší význam pro psychosociální stav. U žen bylo $12 x$ ( $55 \%$ ) uvedeno, že cvičení má pro psychický i fyzický stav stejný přínos, 6 seniorek (27\%) odpovědělo, že má cvičení větší prínos pro jejich psychosociální stav, 4 seniorky (18\%) uvedly, že jim cvičení více prospívá po fyzické stránce.

Získané výsledky jsou velice uspokojivé, nebot nikdo neodpověděl, že se jeho stav zhoršuje, všem se stav subjektivně zlepšil, případně si uchovávají stejné fyzické dispozice, což je při vzrůstajícím věku pozitivní vyjádření. $Z$ toho vyplývá, že pohybový program byl vhodně koncipován a přinesl všem, kteří se ho účastnili, kladný výsledek.

\subsection{Vztahy ve skupině}

Další blok otázek se týkal vztahů ve skupině. Na otázku Jsou zde lidé, které máte rád(a)?, odpověděli oba muži shodně - ano, všechny. Skupina seniorek odpovídala následovně: 13 odpovědělo - ano, všechny, 7 odpovědělo - ano, většinu, 1 odpověd' uváděla - některé. Jedna seniorka na tuto otázku neodpově- 
děla. Můžeme tedy sledovat rozdíl přístupu mezi mužskou a ženskou složkou. Muži shodně odpovídají, že mají rádi všechny účastníky. Ženy však ostatní účastníky programu rozdělují do skupin podle větších či menších vzájemných sympatií.

Také nás zajímalo, zdali probandi vyhledávají kontakt s dalšími účastníky intervenčního programu i mimo cvičební lekce. V př́padě mužů jeden kontakt s ostatními mimo cvičební lekce vyhledává, druhý nikoliv. Pokud se mimo cvičení s ostatními setkává, pak se jedná většinou o procházky nebo o společenská setkání. U žen uvedlo odpověd” „ano“ 14 seniorek (70 \%), 6 seniorek (30\%) odpovědělo „ne, nescházím“, 2 dámy na otázku neodpověděly. Nejčastějším důvodem k setkávání dam mimo intervenční program jsou procházky, tak odpovědělo 6 žen, návštěvy kaváren a restauračních zařízení uvedly 4 ženy, nákupy, přednášky, dovolené, veřejné akce uvedly vždy 2 dámy, 1 dáma napsala setkání v kostele. Pokud se tedy senioři setkávají mimo intervenční program, důvodem $k$ tomu je většinou pohybová činnost či jiná společenská událost.

\subsection{Aktivity seniorů mimo intervenční program}

Zásadní otázkou bylo, zda senioři navštěvují další řízené pohybové aktivity. Oba muži uvedli shodně, že žádný další druh cvičení nenavštěvují. Pouze 2 ženy (9\%) z 22 uvedly další cvičení, a to jedna z mladších účastnic programu cvičení při hudbě v Sokole Královo Pole a druhá cvičení v klubu důchodců. Proto usuzujeme, že náš pohybový program je pro danou skupinu seniorů dostatečný a optimálně náročný, nebot̉ nemají důvod vyhledávat další řízené pohybové aktivity a kompenzovat tak př́ípadný nedostatek řízené formy pohybových aktivit.

Nejčastěji jmenovanou pohybovou aktivitou mimo intervenční program jsou vycházky. Proto jsme se dotazovali, kolik seniorů chodí pravidelně na procházky, př́ípadně jak často a na jakou dobu. 13 dotázaných žen (62\%) odpovídalo „Ano, chodím pravidelně na procházky“, 4 (19\%) odpovídaly „Ne, nechodím“, 4 (19\%) odpovědi uváděly „Občas“. Pokud respondentky odpovídaly kladně, potom v týdenním součtu se údaje pohybovaly mezi 6 a 28 hodinami týdně. Vše záleželo především na počasí, pokud bylo hezčí, byl delší i čas věnovaný procházkám. Jedna seniorka na otázku neodpověděla. První z mužů odpověděl, že pravidelně na procházky nechodí, druhý uvedl, že pravidelně procházkám věnuje 2 hodiny denně. Je zřejmé, že senioři pravděpodobně více času věnují procházkám o víkendech než v běžných pracovních dnech.

Usuzujeme, že čas věnovaný vycházkám je větší než u běžné populace tohoto věku. Někteří senioři chodí na procházky v průměru až 4 hodiny denně. Do svého denního režimu se snaží zařadit i další vlastní různorodé aktivity, hlídání vnoučat a další povinnosti, které probíhají především v pracovním týdnu. $\mathrm{Z}$ toho usuzujeme, že vycházkami zaplňují své méně časově vytížené víkendy.

\section{Závěr}

Intervenční program navštěvuje skupina seniorů s převážně středoškolským vzděláním. Jedná se o skupinu s vyšším průměrným vzděláním ve srovnání s populací tohoto věku. Naši probandi mají zájem o setkání s podobně orientovanými vrstevníky, jako jsou sami, a o navazování nových sociálních vazeb. Vyšší vzdělání s sebou přináší snahu o udržování přehledu. Díky pravidelnému získávání informací jsou si všichni účastníci programu vědomi pozitivního vlivu cvičení na svůj zdravotní stav. Můžeme proto usuzovat na vazbu mezi vyšší mírou vzdělání a účastí v intervenčním programu. Intervenční program může v tomto př́padě sloužit jako vědomý prostředek pozitivního působení na psychický i fyzický stav zúčastněných seniorů.

Srovnatelná pohybová aktivita mužů a žen je patrná v období dětství. Ve středním věku u ženské složky pravidelná pohybová aktivita ustupuje, naopak muži jsou stále aktivní. V období stáří opět dochází ke změně. Ženy jsou ve starším věku výrazně aktivnější v oblasti pohybových aktivit než muži. Většina žen častěji vyhledává i další aktivity, např. procházky, ale stále vykonává i fyzickou práci, úklid domácnosti, zajištuje všechny potřebné domácí práce, hlídá vnoučata, což u mužů absentuje.

Mezi hlavní motivační faktory účasti v intervenčním programu patř́i zvýšení kvality života ve stárí. Senioři se snaží kladně působit pomocí pravidelné pohybové aktivity na své zdraví, snaží se zachovat co 
nejdelší vlastní soběstačnost, ale také o udržovat a navazovat nové př́átelské vazby, trávit čas v kolektivu svých vrstevníků, a pozitivně tak působit na vlastní psychiku.

Rozdíly mezi mužskou a ženskou složkou probandů jsme získali v oblasti vztahů ve skupině. Muži shodně odpovídali, že mají rádi všechny účastníky intervenčního programu. Ženy naopak cvičence rozdělují do skupin dle větších či menších sympatií.

V intervenčním programu výrazně převažuje zastoupení žen nad mužskou složkou. Snažili jsme se vymezit alespoň základní přičiny tohoto stavu. Obecně lze říci, že zastoupení žen je v populaci tohoto věku vyšší. Ženy jsou také družnější, proto více vyhledávají skupinové aktivity, ve kterých probíhá sociální kontakt. Dalším důvodem může být i skutečnost, že ženy podstatně lépe vnímají své tělo a dokážou při cvičení reagovat na navozenou situaci, lépe se sebehodnotí, a tak by pro ně mohlo mít cvičení větší př́ínos než pro muže.

Získané výsledky působení intervenčního programu na jeho účastníky jsou velice uspokojivé, nebot nikdo neodpověděl, že se jeho stav v čase zhoršuje, všem se stav subjektivně zlepšil, případně si uchovávají stejné fyzické dispozice, což je při vzrůstajícím věku pozitivní vyjádření. Z toho vyplývá, že pohybový program byl vhodně koncipován a přinesl všem probandům, kteří se jej aktivně účastnili, kladný výsledek. Proto usuzujeme, že náš pohybový program byl pro danou skupinu seniorů dostatečný a optimálně náročný, nebot' neměli důvod vyhledávat další řízené pohybové aktivity, a kompenzovat tak případný nedostatek ř́zené formy pohybových aktivit.

Závěrem můžeme shrnout, že životní spokojenost zúčastněných seniorů pozitivně ovlivňuje dokládaná radost $\mathrm{z}$ vykonávaných pohybových aktivit, nové sociální vazby, pravidelné kontakty účastníků jak ve cvičení, tak mimo ně, pravidelné vycházky, vhodně zvolená náplň intervenčního programu, pozitivní působení na tělesné sebehodnocení a na všechny složky zdraví ve smyslu bio-psycho-socio-spirituální pohody.

\section{Literatura}

BLAHUTKOVÁ, M. Pohyb a duševní zdraví. Brno : Paido, 2005. ISBN 80-7315-108-1

FAHRENBERG, J. et al. Dotazník životní spokojenosti. Praha : Testcentrum, 2001, ISBN 80-86471-16-0.

FIALOVÁ, L. Kvalita života, sport a tělesné „já“. In Psychosociální funkce pohybových aktivit jako součást kvality života dospělých, s.21-36. Praha : FTVS UK, 2007. ISBN 978-80-86317-53-3

HENDL, J. Kvalitativní výzkum. Základní metody a aplikace. Praha : Portál, 2005. ISBN 80-7367040-2.

HOŠEK, V. Kinezioprotekce kvality života a kinezioterapie duševních poruch. In Psychosociální funkce pohybových aktivit jako součást kvality života dospělých. Praha : FTVS UK, 2007 s. 5-8. ISBN 978-80-86317-53-3

KAVALÍR̆, P. Sportovní aktivity a jejich místo v hodnotových preferencích. In Psychosociální funkce pohybových aktivit jako součást kvality života dospělých, s. 37-44. Praha : FTVS UK, 2007. ISBN 978-80-86317-53-3

KALVACH, Z. et al. Geriatrie a gerontologie. 1. vyd. Praha : Grada publishing, 2004. ISBN 80-247-0548-6 KOZÁKOVÁ, Z.; MÜLLER, O. Aktivizační prístupy k osobám seniorského věku. Olomouc: UPOL, 2006. ISBN 80-244-1552-6

KUBÍČKOVÁ, M. Stáří jako životní šance. 2. vyd. Praha : ONYX, 1996. ISBN 80-85228-07-6

ŠTILEC, M. Pohybové činnosti jako prostředek aktivního stylu života seniorů. Disertační práce, Praha : FTVS UK, 2001

ŠTILEC, M.; BUNC, V. Aktivní styl života seniorů. In Psychosociální funkce pohybových aktivit jako součást kvality života dospělých. Praha: FTVS UK, 2007, s. 232-243. ISBN 978-80-86317-53-3

Českýstatistickýúrad ČR [online].Praha, Česká republika:Českýstatistickýúřad. Posl.úpravy 9.3.2011 [cit. 10.3.2011]. Dostupné na WWW:< http://www.czso.cz/csu/2009edicniplan.nsf/t/ 110033A865/\$File/06_ kap.pdf > 